\title{
The Effect Of Reading Strategy And Personality On EFL Students' Reading Comprehension at STIE TRIBUANA
}

\author{
Tiara Noviarini \\ Universitas Mitra Karya, Bekasi, Indonesia \\ email: tiaranoviarini140315@gmail.com
}

\begin{abstract}
:
By interviewing four students at the Manajement Study Program in STIE Tribuana, the researcher found that the students face some problems when reading English texts. The problems found were important to be investigated because students' reading comprehension play an essential part to improve their English ability from reading text. This research was conducted at STIE Tribuana. This research used descriptive quantitative approach. The respondents were divided into two groups: experimental group and comparison group. The experimental group was treated by using PQ4R strategy while comparison group was treated using CSR strategy. Each group consisted of 14 extroverted students and introverted students. The data were collected using reading test (35 items in the form of multiple choice) and personality questionnaire. The result revealed that there was no significant difference between students who use PQ4R and those who use Collaborative Strategic Reading (CSR) on their reading comprehension. The second one was there was no a significant difference between introverted students and extroverted students on their reading comprehension. The last one was that there was no a significant interaction between reading strategy and personality in their effect on students' reading comprehension.
\end{abstract}

Keywords: Reading Strategy, Personality and Students' Reading Comprehension

\section{INTRODUCTION}

English is taught as a Foreign language in Indonesia. English language has four skills: listening, speaking, reading and writing. Reading in English as Foreign language setting has main goal for EFL students to gain the information, pleasure and any purpose for their studies (Richards, 2002). Furthermore, reading can be a process to acquire the English language. It is because in reading activity the students can learn the language construction and build their vocabulary of the target language. Knowing the important of ELT-Lectura, Vol 8, No 1, February 2021 reading as the language acquisition and educational needs for EFL students, it is surely that students' reading skill should be improved in order to absorb the knowledge of English as well as comprehend the various English text. EFL students usually face some problems related to their comprehension in reading English texts.

In this case the researcher investigated some students in STIE Tribuana Bekasi by doing preliminary observation. By interviewing four students at the Management Study Program, the 
researcher found that the students face difficulity to comprehend English text due to lack of vocabulary. The students also added that the way teacher teach reading material was not interested. The teacher only asked the students to translate English text into Indonesian to get the meaning of the text. Furthermore, the teacher wrote down the difficult words on the board then pronounce them together with students and then translating together by using dictionary. And finally the teacher asked the students to answer the questions provided in the text. One of students also added that the teacher sometimes asked them directly to translate the text then answer the questions. If the students face obstacles in answering the questions, the teacher discussed it together in the class to get the answer.

The problems found above were important to be investigated because students' reading comprehension play an essential part to improve their English ability. The problems as described above raised the researcher to conduct a research related to the nature of reading comprehension of the senior high school students. In line with what was described above, the researcher proposed two strategies in teaching reading to overcome students' problems in comprehending English texts. The strategies proposed by the researcher were PQ4R (preview, question, read, recite, reflect and review) and CSR (Collaborative Strategic Reading). Personality type focused by the researcher on this study was introverted and extroverted. The researcher chose PQ4R and CSR strategies with assumption that PQ4R seems effective for introverted students and CSR was more effective for extroverted ones. In addition, PQ4R strategy is commonly applied for individual reader to depict what is read and build comprehension (Robert, 2006). In contrast (Rathyon, 2004) said CSR can be applied to teach reading comprehension and build vocabulary of the readers by working cooperatively.

PQ4R and CSR strategies provided different learning atmosphere with a hope that both might be effective to teach reading comprehension with different personality among the students. Since introverted students were more interested in quite situation then read the text independently without much interaction with others, PQ4R might be effective for them. While, extroverted students tend to be more active in interaction with other people in their learning circle, they might be comfortable with CSR strategy during reading activity. The choices of using reading strategies in teaching reading determine a success or even failure in language learning process and students' achievement.

\section{METHOD}

In this study, the researcher used causal-comparative research design that involves selecting two or more groups that differ on a particular variable of interest and comparing them on another variable or variables.Furthermore, the researcher applied $2 \times 2$ factorial design with two levels of personality (extrovert and introvert) and two levels of reading strategies (PQ4R and CSR). It was conducted at the second semester in academic year 2019-2020. The participant of this research was the Management Study Program students of STIE Tribuana. The data collecting techniques used in this 
research were reading comprehension test and questionnaire. To analyze the data, the researcher used two-way ANOVA for hypothesis testing. To avoid miscounting, the researcher used SPSS (Stastical Product and Service Solution) version 20.

\section{FINDINGS AND DISCUSSION Findings}

In this research, the researcher formulated three research questions that were elaborated in the following section.

Research Question 1: Is there any significant difference between students who use PQ4R and those who use Collaborative Strategic Reading (CSR) on their reading comprehension?

To answer the research questions, the researcher analyzed the data from students' post-test score of reading comprehension test. The data was analyzed by using Two way Analysis of Variances (ANOVA) and calculated by using SPSS. The results of the data analysis can be seen from the following table:

Table 4.6

Tests of Between-Subjects Effects ${ }^{\mathrm{a}}$

Dependent Variable: Reading Comprehension

\begin{tabular}{llll}
\hline Source & \multicolumn{1}{c}{ F } & Sig. & $\begin{array}{l}\text { Partial Eta } \\
\text { Squared }\end{array}$ \\
\hline Corrected Model & ,792 &, 504 &, 044 \\
Intercept & 8382,499 &, 000 &, 994 \\
A & $\mathbf{, 9 9 8}$ & $\mathbf{, 3 2 2}$ &, 019 \\
B & $\mathbf{, 2 8 6}$ & $\mathbf{, 5 9 5}$ &, 005 \\
A * B & $\mathbf{1 , 0 9 3}$ & $\mathbf{, 3 0 1}$ &, 021 \\
Error & & & \\
Total & & & \\
Corrected Total & & & \\
\hline
\end{tabular}

a. R Squared $=, 044$ (Adjusted R Squared $=$ $-, 011)$

Source: Data Analysis
The first hypothesis was to test whether there was a significant difference between students who taught using PQ4R strategy and those who taught using CSR strategy on their reading comprehension. From the finding above (see Table 4.6), the "sig" of variable A (reading strategy) was 0.322 . It was known that the $p$-value was bigger than $\alpha=0.05$. So the null hypothesis $\left(\mathrm{H}_{0}\right)$.

It was accepted and the alternative one was rejected. To ensure that the result was constant, the Critical value approach was used as the standard. It was derived by comparing $F$ statistics to $F \alpha$. F statistics could be seen from the finding above (see Table 4.6) and F $\alpha$ could be found from $F$ distribution:

Critical Value of F 5\% significance level (see Appendix 15). It was known the result of $F$ statistics in this research was 0.998. While, $\mathrm{F} \alpha$ in this research was 4.030 since the sample number was 56 . The hypothesis would be accepted if $F$ statistics was less than $F \alpha$ and vice versa. We can see from the finding that $\mathrm{F}$ statistics was less than $F \alpha(F=0.998<F \alpha=4.030)$. So the null hypothesis was accepted and the alternative one was rejected.

Since both $\mathrm{p}$-value and Critical-value had the same result (accepted $\mathrm{H}_{0}$ ), it can be interpreted that the students who taught using PQ4R strategy were not significantly different from those who taught using CSR strategy on their reading comprehension. To support the result above, we can also see Table 4.7 below: 
Tabel 4.7.

Descriptive Statistics Dependent

Variable: Reading Comprehension

\begin{tabular}{|c|c|c|c|c|}
\hline $\begin{array}{l}\text { Readin } \\
\text { g } \\
\text { Strateg }\end{array}$ & $\begin{array}{l}\text { Personalit } \\
\text { y }\end{array}$ & $\begin{array}{l}\text { Mean } \\
\text { s }\end{array}$ & $\begin{array}{l}\text { Std. } \\
\text { Deviatio } \\
n\end{array}$ & $\mathrm{~N}$ \\
\hline $\mathrm{y}$ & & & & \\
\hline \multirow{3}{*}{ PQ4R } & Extrovert & $\begin{array}{l}69,9 \\
3 \\
\end{array}$ & 69,93 & $\begin{array}{l}1 \\
4\end{array}$ \\
\hline & Introvert & $\begin{array}{l}72,3 \\
6\end{array}$ & 72,36 & $\begin{array}{l}1 \\
4\end{array}$ \\
\hline & Total & $\begin{array}{l}71,1 \\
4\end{array}$ & 71,14 & $\begin{array}{l}2 \\
8\end{array}$ \\
\hline \multirow{3}{*}{ CSR } & Extrovert & $\begin{array}{l}70,0 \\
0 \\
\end{array}$ & 70,00 & $\begin{array}{l}1 \\
4\end{array}$ \\
\hline & Introvert & $\begin{array}{l}69,2 \\
1\end{array}$ & 69,21 & $\begin{array}{l}1 \\
4\end{array}$ \\
\hline & Total & $\begin{array}{l}69,6 \\
1 \\
\end{array}$ & 69,61 & $\begin{array}{l}2 \\
8 \\
\end{array}$ \\
\hline \multirow{3}{*}{ Total } & Extrovert & $\begin{array}{l}69,9 \\
6 \\
\end{array}$ & 69,96 & $\begin{array}{l}2 \\
8 \\
\end{array}$ \\
\hline & Introvert & $\begin{array}{l}70,7 \\
9 \\
\end{array}$ & 70,79 & $\begin{array}{l}2 \\
8\end{array}$ \\
\hline & Total & $\begin{array}{l}70,3 \\
8\end{array}$ & 70,38 & $\begin{array}{l}5 \\
6\end{array}$ \\
\hline
\end{tabular}

Source: Data Analysis

The result showed that the total mean of students who use PQ4R $(\bar{x}=$ $71,14)$ was not significantly higher than the mean of students who use CSR $(\bar{x}=69,61)$. So, the answer of research question 1 is that there was no significant difference between students who use PQ4R and those who use CSR on their reading comprehension achievement.
Research Questions 2: Is there any significant difference between introverted students and extroverted students on their reading comprehension

The researcher analyzed the data from students' post-test score of reading comprehension test and personality questionnaire to answer the second research questions. From the finding (see Table 4.6) the "sig" of variable B (personality) was 0.595 . It means that the $p$-value was bigger than $\alpha=0.05$ (P-value $=0.595>\alpha=0.05$ ). For Critical value approach, it could be seen from column " $F$ ". It was known that $F$ statistic was 0.286 and $\mathrm{F} \alpha$ was 4.030 ( $\mathrm{F}=$ $0.595<\mathrm{F} \alpha=4.030$ ).

Based on the result above, the null hypothesis $\left(\mathrm{H}_{0}\right)$ was accepted. So it interpreted that extroverted students were not significantly different from introverted students on their reading comprehension. It was also supported from the mean score (see table 4.7) of extroverted students $(\bar{x}=$ $69,96)$ and the mean of introverted students $(\bar{x}=70,79)$. The result showed that the mean score of extroverted students was not significantly lower than the mean score of introverted students. So, it can be drawn that among the students either extrovert or introvert were not significantly different on their reading comprehension achievement. In addition, the type of personality, in this case, did not effect significantly on reading comprehension ability. 
Research Questions 3: Is there any significant interaction between reading strategy and personality in their effect on students' reading comprehension?

The researcher also analyzed the data from students' post-test score of reading comprehension test to answer the third research question. Table 4.6 showed that $\mathrm{p}$ value $(\operatorname{sig})$ for $\mathrm{A} * \mathrm{~B}$ (reading strategy*personality) was 0.301 . It was bigger than $\alpha=0.05$ (P-value $=0.301>\alpha=$ 0.05). Furheremore, F statistics was 1,093 and it was less than $\mathrm{F} \alpha(\mathrm{F}=1.093<\mathrm{F} \alpha=$ 4.030). It means that the null hypothesis was accepted. So, the answer of the third research question was that there was no significant interaction between reading strategy and students' personality. It could also be drawn that students who had different personality (extrovert and introvert) did not significantly effect on the use of reading strategy (PQ4R and CSR).

\section{Discussion}

In this section, the researcher would discuss the results of the research that was related to the previous studies and theory in chapter 2.

There was no significant difference between students who use PQ4R and those who use Collaborative Strategic Reading (CSR) on their reading comprehension

The finding showed that students' reading achievement who applied PQ4R strategy in their reading was not significantly different from those who applied CSR strategy. As stated by Chew and Dunn (2006), "In order to remember material, it is important that students engage in deep or elaborative processing." It was known that both strategies (PQ4R and CSR) were reading strategy which contain eloborative steps to achieve reading comprehension. The procdures of $\mathrm{PQ} 4 \mathrm{R}$ reflect a deep reading process. In addition, Bremer et.a (2015) said, "Collaborative Strategic Reading (CSR)... consists of four comprehension strategies that students apply before, during and after reading in a small cooperative group." It showed that CSR also had similar a deep process to PQ4R in reading activity. From the theory above, it could be related to the research finding that both treatment class did not significantly have different score on their reading comprehension achievement because each strategy applied in both classes had similar a deep process in reading activity. So the result showed that there was no significant difference among the students who taught using PQ4R and CSR strategy on their reading score in posttest.

The finding of this study are in agreement with those of previous studies. Ajar Suwita (2015) also investigated the implementation of PQ4R to enhance students' reading comprehension. The finding of his research was that PQ4R strategy could be used to enhance students' reading comprehension. It could be seen from the post test result that the mean score for identifying main idea, stated detailed information, the meaning of word and pronoun reference increased. In another study, McCown (2013) investigated the effect of CSR on informational text comprehension by using the Qualitative Reading Inventory-5 (QRI-5) and Georgia's Criterion-Referenced Competency Test (CRCT). The result showed that the use of CSR strategy significantly effected 
students' comprehension on informational text.

It was also supported by Kassem (2013) who compared Collaborative Strategic Reading (CSR) and Individual Strategic Reading (ISR) on reading comprehension and reading self-efficacy of EFL learners. The finding revealed that both CSR and ISR achieved significantly gains on reading comprehension and selfefficacy. The result also showed there was no significant differences between students who taught with ISR and those who taught with CSR. It was supported by the finding of this research that students who use PQ4R and those who use CSR were not significantly different on their reading score. From the findings above, it can be said that CSR strategy can be used to help students improve their reading comprehension. CSR can be applied in a group work, it means that each student has opportunity to share what they understand. For example, in the process of reading activity using CSR, the students in a group make a summary by collecting the student's idea of what they comprehend in the text. Then, each group shared with other group in the class about the text they already read. In this step, the students gained more from reading activity in the class.

\section{There was no significant difference between extroverted students and introverted students on their reading comprehension}

The second finding showed that the type of students' personality did not significantly effect their reading comprehension. The result of this research was known that the extroverted students were better than introverted students in using CSR strategy. In addition, Rekabdar, Behrouzi and Hakhverdian (2015) also found that extroverted students had better reading performance in using metacognitive strategy than introverted students. It was supported by situation of teaching and learning process in the class. Extroverted students in comparison group who taught using CSR strategy were more active and enthusiastic in reading the text. Eventhough introverted students were not active enough in comparison group, they were not significantly different in reading achievement.

It was also supported by Bagheri and Faghih (2012) who investigated the relationship between self-esteem, personality type and reading comprehension. The finding showed that extroversion personality did not determine TOEFL reading achievement. The second finding indicated that when the students are extrovert, their self-esteem increase and when the students are introvert their selfesteem decrease. For example, in the process of teaching reading using CSR strategy, the extoverted students seemed so active in their group in doing the task, on the other hand, the introverted students kept quite and shy to share their ideas with their group. In presentation step, the extroverted students were enthusiastic to share the summary in front of the class. From the study conducted by Bagheri and Faghih (2012) also found that there was a relationship between self-esteem and personality. Self-esteem influenced how the way someone interact with others. Furthermore, the researcher saw in the process of teaching and learning by using PQ4R and CSR that the extroverted students and introverted students in the 
class have different interaction with their peers. Extroverted students tend to be active and impressed in doing the task with their group while introverted ones tend to be quite and more concentrated by themselves.

The result was related to the theory of personality by Matthew, Deary and Whiteman (2003) who say, "Extrovert as someone who is sociable, craves excitement, takes chances, is fond of practical jokes, and can at times lose his temper. Introvert is someone who is quiet and retiring, is fond of books rather than people, is serious, and keeps feelings under close control." In the procedure of teaching and learning by using PQ4R, the introverted students looked calm and concencrated with the text while extroverted students were active to ask and move around to their friends. Eventhough between extroverted and intoverted students have different character, the finding in this research showed that they were not significantly different on reading comprehension achievement.

There was no significant interaction between reading strategy and personality in their effect on students' reading comprehension

The relationship between personality difference and reading strategy on students' reading comprehension score had no significant interaction. It happened because the strategy proposed by the researcher might have similarity in process. In addition, the personality type did not influence much in the way the students involve during reading activity by using a certain reading strategy. Khaki (2014) argues, "However, since reading comprehension is an interactive process, teachers can encourage learners to be active while reading text."

Related to the theory above and the finding of this research, it means that the different type of students' personality did not effect on reading strategy they applied. It happens because as stated by Khaki (2014) that as long as the reading activity in the class was interactive, the students would be easy to involve with the text. Since the study on langauge and personality are relatively few in number, the researcher could not compare the finding to others. There would be interaction between reading strategy and personality if a certain type of personality who use certain reading strategy had significant effect on their reading comprehension. For instance, the extroverted students' score who use PQ4R and CSR were higher than all introverted students in both class who use those strategies.

The researcher asserts that students' reading comprehension ability can not be explained by student's personality and reading strategy. To sum up, the result of this research showed that the students' reading comprehension was not being influenced or affected by their use of specific reading strategy and specific types of personality.

\section{CONCLUSION}

Based on the results of the data analysis and discussion, the researcher drew the following conclusions:

1. There was no significant difference between students who use PQ4R strategy and those who use CSR strategy. The finding showed that the p-value of reading strategy was bigger 
than $\alpha=0.05(\mathrm{p}$-value $=0.322>\alpha=0$. $05)$. It can also be seen from the total mean of students who use PQ4R and those use CSR. It was known that the mean score of students who use PQ4R $(\bar{x}=71,14)$ was not significantly higher than the mean of students who use CSR $(\bar{x}=69,61)$.

2. There was no significant difference between extroverted students and introverted students on their reading comprehension. The finding revealed that the $p$-value of variable $B$ (personality) was bigger than $\alpha=0.05$ ( $\mathrm{p}$-value $=0.595>\alpha=0.05)$. Furthermore, the mean score of extroverted students was 69,96 and the mean score of introverted students was 70,79 . It means that the students either extrovert or introvert were not significantly different on their reading comprehension achievement.

3. The interaction between two independent variables did not significantly happen in this research. The choice of using certain reading strategy was not influenced by the diversity of students' personality. The $\mathrm{p}$-value (sig) for $\mathrm{A} * \mathrm{~B}$ (reading strategy*personality) was 0.301 . It was bigger than $\alpha=0.05(\mathrm{P}$-value $=0.301>$ $\alpha=0.05)$. So there was no interaction between reading strategy and personality on students' reading comprehension.

\section{REFERENCES}

Bagheri, M. S. \& Faghih, M. 2012. The Relationship between Self-esteem, Personality Type and Reading Comprehension of Irian EFL Students. Theory and Practice in Language Studies. Vol.2, No.8, pp. 1641-1650, August 2012. Finland: ACADEMY PUBLISHER.

Bremer, C. D., Vaughn, S., Clapper, A. T. \& Kim, H. 2002. Collaborative Strategic Reading: Improving Secondary Students Reading Comprehension Skill. National Center on Secondary Education and Transition. June 2001 vol. 1. Issue $2 . \quad$ P.1. From:https://www.utexas.edu/cola/ centers/tlc/_files/conferences/new medianewmaterials/using_collabor ative.pdf. Retrieved on August 13, 2015

Dunn, D. S \& Chew, S. T. 2006. Best Practice for Teaching Introduction to Psychology. London: Lawrence Erlbaum Associate.

Khaki, N. 2014. Improving Reading Comprehension in a Foreign Language: Strategic Reader. The Reading Matrix. V. 14, no.2. 2014. P. 188. http://www.readingmatrix .com/ Ifiles/11-m9371u67.pdf. Retrieved on August 12, 2015.

Matthews, G., Deary, I. J. \& Whiteman, M. C. 2003. Personality Trait. $2^{\text {nd }}$ ed. The United Kingdom: The press syndicate of the university of cambridge.

McCown, M. A. 2013. The effects of Collaborative Strategic Reading on Informational Text Comprehension and Metacognitive Awareness of Fifth Grade Students. Published doctoral dissertation. Liberty Unversity. 
Rathvon, N. 2004. Academic Intervension.

Ed. Charles Spielberger. Encyclopedia of Applied Psychology, vol.1. Washington, D.C: Center City Consortium School.

Rekabdar, S., Behrouzi, P. \& Hakhverdian, A. 2015. Irian Intermediate Extroverted vs. Introverted Learners and Metacognitive Strategies. International Journal of Educational Investigation. Vol.2, No.1:213-225, 2005. http://www.ijeionline.com/ attachments/article/35/IJEIonline. Retreived on August 15, 2015.

Richards, J. C \& Renandya, A. W. 2002. Methodology in language teaching. New York: Cambridge University Press.

Suwita, A. 2014. Implementing Preview, Question, Read, Reflect, Recite, Review (PQ4R) Strategy to Enhance Students' Reading Comprehension. Published Thesis of Graduate School of English Department, Sebelas Maret University. Repository UNS. 